\title{
Radioprotective effects of cimetidine on rats irradiated by long-term, low-dose-rate neutrons and ${ }^{60} \mathrm{Co}$-rays
}

Ding-Wen Jiang ${ }^{\dagger}$, Qing-Rong Wang ${ }^{\dagger}$, Xian-Rong Shen ${ }^{*}$, Ying He, Tian-Tian Qian, Qiong Liu, Deng-Yong Hou, Yu-Ming Liu, Wei Chen, Xin Ren and Ke-Xian Li

\begin{abstract}
Background: Cimetidine, an antagonist of histamine type II receptors, has shown protective effects against $\psi$-rays or neutrons. However, there have been no reports on the effects of cimetidine against neutrons combined with $\gamma$-rays. This study was carried out to evaluate the protective effects of cimetidine on rats exposed to long-term, low-dose-rate neutron and $\gamma$-ray combined irradiation ( $n-\gamma$ LDR).

Methods: Fifty male Sprague-Dawley (SD) rats were randomly divided into 5 groups: the normal control group, radiation model group, $20 \mathrm{mg} /(\mathrm{kg} \cdot \mathrm{d})$ cimetidine group, $80 \mathrm{mg} /(\mathrm{kg} \cdot \mathrm{d})$ cimetidine group and $160 \mathrm{mg} /(\mathrm{kg} \cdot \mathrm{d})$ cimetidine group (10 rats per group). Except for the normal control group, 40 rats were simultaneously exposed to fission neutrons $\left({ }^{252} \mathrm{Cf}, 0.085 \mathrm{mGy} / \mathrm{h}\right)$ for $22 \mathrm{~h}$ every day and $\mathrm{y}$-rays $\left({ }^{60} \mathrm{Co}, 0.097 \mathrm{~Gy} / \mathrm{h}\right)$ for $1.03 \mathrm{~h}$ once every three days, and the cimetidine groups were administered intragastrically with cimetidine at doses of 20, 80 and 160 $\mathrm{mg} / \mathrm{kg}$ each day. Peripheral blood WBC of the rats was counted the day following exposure to $\gamma$-rays. The rats were anesthetized and sacrificed on the day following exposure to ${ }^{252} \mathrm{Cf}$ for 28 days. The spleen, thymus, testicle, liver and intestinal tract indexes were evaluated. The DNA content of bone marrow cells and concanavalin A (ConA)induced lymphocyte proliferation were measured. The frequency of micronuclei in polychromatic erythrocytes ( $(\mathrm{MNNPCES)}$, superoxide dismutase (SOD), malondialdehyde (MDA), and glutathione peroxidase (GSH-Px) in the serum and liver tissues were detected.
\end{abstract}

Results: The peripheral blood WBC in the cimetidine groups was increased significantly on the 8th day and the 26th day compared with those in the radiation model group. The spleen, thymus and testicle indexes of the cimetidine groups were higher than those of the radiation model group. The DNA content of bone marrow cells and lymphocyte proliferation in the cimetidine groups were increased significantly, and fMNPCE was reduced 1.41-1.77 fold in cimetidine treated groups. The activities of SOD and GSH-Px in the cimetidine groups were increased significantly, and the content of MDA in the cimetidine groups was decreased significantly.

Conclusions: The results suggested that cimetidine alleviated damage induced by long-term, low-dose-rate neutron and $y$ combined irradiation via antioxidation and immunomodulation. Cimetidine might be useful as a potent radioprotector for radiotherapy patients as well as for occupational exposure workers.

Keywords: Cimetidine, Radioprotection, Antioxidation, Immunomodulation, Micronuclei

\footnotetext{
* Correspondence: xianrong_sh@163.com

${ }^{\dagger}$ Equal contributors

The PLA Key Laboratory of Biological Effect and Medical Protection on Naval Vessel Special Environment, Naval Medical Research Institute, Xiangyin Road 880, Shanghai 200433, China
} 


\section{Background}

Most of the data on radioprotection have been derived from studies using low linear energy transfer (LET) Xand $\gamma$-radiation. Exposure to high LET radiation can also be expected during long-term space flights, occupational exposure in nuclear plants, and tumor radiotherapy. It was demonstrated that neutrons and other high LET radiation induce more severe biological effects than low LET radiation for the same absorbed dose $[1,2]$. Thus, protection against high LET radiation should be given more attention. It was observed that cysteine with a dose reduction factor (DRF) of 1.7 for $\gamma$-rays was shown to have a DRF of only 1.1 in mice against neutrons [3]. From the discovery of the radio-protective effect of cysteine, increasingly more compounds have been used in an attempt to provide partial protection against radiation injury. However, thus far, sulfhydryl compounds remain the main radioprotectors, such as mercapto-ethylamine (MEA), aminethylisothiouronium (AET) and amifostine (WR2721) [4]. However, the side effects of these radioprotectors have limited their clinical application [5]. Therefore, the development of new drugs that are less toxic and effective even for high LET exposure is desired for the protection of medical and occupational exposure to radiation.

Cimetidine, an antagonist of histamine type II receptors that is usually used for peptic ulcer treatment, has shown protective effects against radiation, not only high LET neutrons but also low LET $\gamma$ or X-rays. Cimetidine was shown to be effective against the clastogenic effects of $\gamma$-rays [6, 7] and X-rays [8] in vitro. It was also demonstrated to be protective against $\gamma$-rays and neutrons in vivo [7, 9-12]. Cimetidine was shown to inhibit the activity of suppressor $\mathrm{T}$ cells [13] and was used in radioprotection to help the recovery of the lymphohematopoietic system effectively [10]. $\mathrm{H}_{2}$-receptor antagonists have potential oxygen-radical-scavenging properties. It was reported that cimetidine could scavenge $\mathrm{OH}$ with a very high rate constant [14]. Mice treated with cimetidine could tolerate biomembrane damage provoked by sublethal $\gamma$-radiation. This supports the hypothesis that cimetidine may afford efficient protection against ionizing radiation or diseases that are characterized by in vivo free radical-mediated oxidative stress mechanisms [15]. It was shown that cimetidine, ranitidine, and famotidine produced a DRF of 1.5 to 2 against $\gamma$-ray-induced micronuclei in mouse bone marrow erythrocytes $[9,16]$. Cimetidine, compared with famotidine, was found to be more protective against mortality induced by radiation in mice [12].

In this study, SD rats were exposed to long-term, lowdose-rate neutron and $\gamma$ combined irradiation ( $n-\gamma$ LDR) with or without cimetidine supplementation, and the protective effects of cimetidine on rats exposed to $n-\gamma$ LDR were reported.

\section{Methods}

\section{Materials}

Cimetidine was purchased from Tianjin Smith Kline \&French Laboratories Ltd (Tianjin, China). Superoxide dismutase (SOD), malondialdehyde (MDA), and glutathione peroxidase (GSH-Px) kits were purchased from the Nanjing Jiancheng Bioengineering Institute.

\section{Animals and treatments}

Five-week-old male SD rats were purchased from SinoBritish SIPPR/BK Lab. Animal Co. Ltd. The rats were maintained under conditions of standard lighting (12:12 h light-dark cycle), temperature $\left(20-22{ }^{\circ} \mathrm{C}\right)$ with freely available food and water. The animals were randomly divided into 5 groups $(n=10)$ : normal control group, radiation model group, $20 \mathrm{mg} /(\mathrm{kg} \cdot \mathrm{d})$ cimetidine group, $80 \mathrm{mg} /(\mathrm{kg} \cdot \mathrm{d})$ cimetidine group and $160 \mathrm{mg} /$ (kg.d) cimetidine group. Cimetidine was administered by intragastric infusion with the volume of $10 \mathrm{ml} / \mathrm{kg}$ each day. The Institutional Animal Care and Use Committees of the Naval Medical Research Institute approved all procedures for animal care and treatment.

\section{Animal irradiation}

From the first day of cimetidine administration, animals, except those in the normal control group, were wholebody exposed to fission neutrons $\left({ }^{252} \mathrm{Cf}, 0.085 \mathrm{mGy} / \mathrm{h}\right.$, the Radiation Center of the Naval Medical Research Institute) $22 \mathrm{~h}$ every day for 28 days, and $\gamma$-rays $\left({ }^{60} \mathrm{Co}\right.$, $0.097 \mathrm{~Gy} / \mathrm{h}$, the Radiation Center of the Naval Medical Research Institute) $1.03 \mathrm{~h}$ once every three days. The cumulative doses were $52.36 \mathrm{mGy}$ of neutron and $1.0 \mathrm{~Gy}$ of $\gamma$-rays. The radiation method and doses are shown in Table 1.

\section{Peripheral blood white blood cell (WBC) count}

Whole blood was collected from the rat tail into EDTAcoated tubes on the 3rd day before radiation and on the 8 th, 17th and 26th days after radiation, and the absorbed doses of neutrons and $\gamma$-rays on these days are shown in Table 1. Peripheral blood WBC counts were obtained using a veterinary hematology analyzer (Nihon Kohden Corporation, Japan) according to the operator's manual.

Table 1 Accumulated dose of $n-\gamma$ LDR on the day of vein blood collection

\begin{tabular}{lcccc}
\hline Radiation & 8th day & 17th day & 26th day & 29th day \\
\hline Neutron (mGy) & 13.09 & 29.92 & 46.75 & 52.36 \\
Y-rays (Gy) & 0.3 & 0.6 & 0.9 & 1.0 \\
\hline
\end{tabular}

The 8th, 17th, 26th and 29th day indicates the time points of vein blood collection; at these time points, the rats were actually exposed to $n-\gamma$ LDR for $7,16,25$ and 28 days 


\section{Organ weight index detection}

Animals were anesthetized and sacrificed on the next day after exposure to ${ }^{252} \mathrm{Cf}$ for 28 days. The spleen, thymus, testicle, liver, and intestinal tract were separated, and organ indexes were determined using the following equation: Organ index = organ weight/body weight.

\section{Bone marrow DNA content detection}

The next day after finished all the irradiation, the right femur of each animal was removed and cleaned of adherent tissues. The bone marrow was flushed into $5 \mathrm{ml}$ of a $5-\mathrm{mmol} / \mathrm{L} \mathrm{CaCl}{ }_{2}$ solution and was incubated at $4{ }^{\circ} \mathrm{C}$ for $30 \mathrm{~min}$. Cell suspensions were centrifuged at 2,500 r/ min for $15 \mathrm{~min}$, and the pellet was resuspended in $5 \mathrm{ml}$ $0.2 \mathrm{~mol} / \mathrm{L} \mathrm{HClO}_{4}$. The suspension was incubated at $90{ }^{\circ} \mathrm{C}$ for $15 \mathrm{~min}$ and was filtered through a $0.22-\mu \mathrm{m}$ membrane. The absorbance at $260 \mathrm{~nm}$ was detected using a 759 UV spectrophotometer (Shanghai APL instrument Co., Ltd.).

\section{Detection of SOD, MDA, and GSH-Px in serum and hepatic tissue}

The next day after finished all the irradiation, blood was collected from the inferior vena cava into clean centrifuge tubes. Serum was prepared by centrifugation at $3,000 \times g$ for $15 \mathrm{~min}$. Next, $100 \mathrm{mg}$ of hepatic tissue filled with $0.9 \mathrm{ml}$ of normal saline was homogenized with a pulping machine, and the supernatant was prepared by centrifugation at $3,000 \times g$ for $15 \mathrm{~min}$. SOD, MDA, and GSH-Px in serum and hepatic tissue supernatants were determined using detecting kits from Nanjing Jiancheng Bioengineering Institute according to the manufacturer's instructions.

\section{Concanavalin A (ConA)-induced splenocyte proliferation assay}

The next day after finished all the irradiation, splenic lymphocytes were prepared as previously described [17]. One milliliter of spleen cell suspension $\left(3 \times 10^{6}\right.$ cells $\left./ \mathrm{ml}\right)$ was added into 24-well plates and cultured with $75 \mu \mathrm{l}$ of $100 \mu \mathrm{g} / \mathrm{ml}$ ConA solution. The plates were incubated at $37{ }^{\circ} \mathrm{C}$ with $5 \% \mathrm{CO}_{2}$ for $68 \mathrm{~h}$, and then $0.7 \mathrm{ml}$ of supernatant in each well was discarded and $0.7 \mathrm{ml}$ of RPMI
1640 medium was added. Next, $50 \mu \mathrm{l}$ of fresh prepared MTT solution ( $5 \mathrm{mg} / \mathrm{ml}$, dissolved in PBS, $\mathrm{pH} 7.2$ ) was added into each well and incubated under the same conditions for $4 \mathrm{~h}$. Finally, $1 \mathrm{ml}$ of acid-isopropanol solution ( $1 \mathrm{~mol} / \mathrm{L} \mathrm{HCl} /$ isopropanol was $4 / 96(v / v)$ ) was added into each well and mixed thoroughly until the purple crystals were fully dissolved. The absorbance at $570 \mathrm{~nm}$ was determined.

\section{Detection of the frequency of micronuclei in} polychromatic erythrocyte (fMNPCE) in the bone marrow The next day after finished all the irradiation, bone marrow samples were collected from the left femur of each animal. The bone marrow was flushed into $1.5-\mathrm{ml}$ tube used by $400 \mu \mathrm{l}$ of fetal bovine serum (FBS), and then $200 \mu \mathrm{l}$ of suspension was fixed by adding $5.0 \mathrm{ml}$ of $1 \%$ glutaraldehyde solution containing $30 \mu \mathrm{l} / \mathrm{ml} \mathrm{SDS}$ and $0.05 \mathrm{~mol} / \mathrm{L}$ Sorensen. The fixed cells were incubated for $5 \mathrm{~min}$ and then were centrifuged at $300 \times g$ for $5 \mathrm{~min}$. The cell pellets were suspended in $1.0 \mathrm{ml}$ of acridine orange staining solution and staining for $30 \mathrm{~min}$ at $37^{\circ} \mathrm{C}$. The stained cells were analyzed using the Accuri C6 flow cytometer (BD Biosciences, NJ, USA). At least 10,000 cells/sample were collected, and the fMNPCE was analyzed.

\section{Statistical analysis}

Statistical analysis was performed by one-way analysis of variance (AVOVA) followed by LSD $t$-test using SPSS (version 16.0). All of the values were expressed as mean as the means \pm standard deviation (SD). $P$ values $<0.05$ were considered to be statistically significant.

\section{Results}

Protection effect of cimetidine on peripheral blood WBC of irradiated rats

The results are shown in Table 2. Peripheral blood WBC in all groups was not significantly different on the 3rd day before radiation $(P>0.05)$. WBC in the irradiation groups was decreased significantly on the 8th, 17th and 26 th days, respectively $(P<0.01)$. On the 8 th day, WBC in the cimetidine groups was increased significantly compared with that in the radiation model

Table 2 Effect of cimetidine on peripheral blood WBC counts in $n-\gamma$ LDR rats $\left(\times 10^{9} / L, x \pm s, n=10\right)$

\begin{tabular}{lclll}
\hline Group & 3rd day before IR & 8th day & 17th day & 26th day \\
\hline Normal control group & $10.9 \pm 1.6$ & $11.6 \pm 1.2$ & $10.7 \pm 1.2$ & $10.0 \pm 2.6$ \\
Radiation model group & $10.8 \pm 2.2$ & $7.7 \pm 1.0^{(1)}$ & $8.2 \pm 2.3^{(1)}$ & $6.3 \pm 0.7^{(1)}$ \\
$20 \mathrm{mg} /(\mathrm{kg} \cdot \mathrm{d})$ cimetidine group & $10.7 \pm 1.5$ & $11.3 \pm 2.1^{(3)}$ & $8.6 \pm 1.3^{(1)}$ & $7.2 \pm 1.2^{(1)(2)(4)}$ \\
$80 \mathrm{mg} /(\mathrm{kg} \cdot \mathrm{d})$ cimetidine group & $10.6 \pm 1.7$ & $9.0 \pm 1.6^{(1)(2)}$ & $7.9 \pm 1.1^{(1)}$ & $7.2 \pm 1.0^{(1)(2)(4)}$ \\
$160 \mathrm{mg} /(\mathrm{kg} \cdot \mathrm{d})$ cimetidine group & $10.5 \pm 1.5$ & $9.0 \pm 1.9^{(1)}$ & $8.4 \pm 1.2^{(1)}$ & $5.8 \pm 1.2^{(1)}$ \\
\hline
\end{tabular}

${ }^{(1)} p<0.01$ compared with the normal control group; ${ }^{(2)} p<0.05,{ }^{(3)} p<0.01$ compared with the radiation model group; ${ }^{(4)} p<0.05$ compared with the $160 \mathrm{mg} /(\mathrm{kg} \cdot \mathrm{d})$ cimetidine group. The 8 th, 17 th and 26 th day were the days that the rats were exposed to $n-\gamma$ LDR for 7,16 and 25 days, respectively 
Table 3 Effect of cimetidine on the organ indexes of $n-\gamma$ LDR rats $(\mathrm{mg} / \mathrm{g}, x \pm s, n=10)$

\begin{tabular}{lllllc}
\hline Group & Spleen index & Thymus index & Testicle index & Liver index & Intestinal tract index \\
\hline Normal control group & $2.16 \pm 0.21$ & $1.75 \pm 0.14$ & $8.20 \pm 0.83$ & $33.75 \pm 4.01$ & $0.38 \pm 0.03$ \\
Radiation model group & $1.74 \pm 0.22^{(2)}$ & $1.41 \pm 0.26^{(1)}$ & $7.44 \pm 0.46^{(1)}$ & $32.81 \pm 1.63$ & $0.37 \pm 0.03$ \\
$20 \mathrm{mg} /(\mathrm{kg} \cdot \mathrm{d})$ cimetidine group & $2.02 \pm 0.23^{(4)}$ & $1.69 \pm 0.29^{(3)}$ & $7.88 \pm 0.58$ & $32.03 \pm 1.24$ & $0.38 \pm 0.02$ \\
$80 \mathrm{mg} /(\mathrm{kg} \cdot \mathrm{d})$ cimetidine group & $1.89 \pm 0.21^{(1)}$ & $1.64 \pm 0.31$ & $7.60 \pm 0.61$ & $31.63 \pm 2.15$ & $0.38 \pm 0.02$ \\
$160 \mathrm{mg} /(\mathrm{kg} \cdot \mathrm{d})$ cimetidine group & $1.91 \pm 0.14^{(2)(3)}$ & $1.63 \pm 0.29$ & $7.94 \pm 0.49^{(3)}$ & $34.34 \pm 3.25$ & $0.39 \pm 0.03$ \\
\hline
\end{tabular}

${ }^{(1)} P<0.05,{ }^{(2)} P<0.01$ compared with the normal control group; ${ }^{(3)} P<0.05,{ }^{(4)} P<0.01$ compared with the radiation model group

group $(P<0.01$ in the $20 \mathrm{mg} /(\mathrm{kg} \cdot \mathrm{d})$ group, $P<0.05$ in the $80 \mathrm{mg} /(\mathrm{kg} \cdot \mathrm{d})$ group $)$. On the 26 th day, $\mathrm{WBC}$ in the $20 \mathrm{mg} /(\mathrm{kg} \cdot \mathrm{d})$ and $80 \mathrm{mg} /(\mathrm{kg} \cdot \mathrm{d})$ cimetidine groups was increased significantly compared with that in the radiation model group $(P<0.05)$. These results suggested that cimetidine has a promotion effect on peripheral blood WBC of $\mathrm{n}-\gamma$ LDR rats.

\section{Protection effect of cimetidine on the organ indexes of irradiated rats}

The results are shown in Table 3. The spleen indexes, thymus indexes, and testicle indexes of the radiation model group were decreased significantly compared with those of the normal control group $(P<0.05$ or $P<0.01)$, and the liver indexes and intestinal tract indexes showed no significant difference $(P>0.05)$. The spleen indexes of the cimetidine groups were increased compared with those of the radiation model group $(P<0.01$ in the $20 \mathrm{mg} /(\mathrm{kg} \cdot \mathrm{d})$ cimetidine group and $P<0.05$ in the $160 \mathrm{mg} /(\mathrm{kg} \cdot \mathrm{d})$ cimetidine group). The thymus indexes of the $20 \mathrm{mg} /(\mathrm{kg} \cdot \mathrm{d})$ cimetidine group were increased compared with those of the radiation model group $(P<$ $0.05)$. The testicle indexes of the $160 \mathrm{mg} /(\mathrm{kg} \cdot \mathrm{d})$ cimetidine group were increased compared with those of the radiation model group $(P<0.05)$. The liver indexes and intestinal tract indexes in all groups showed no significant difference $(P>0.05)$. These results suggested that $\mathrm{n}-\gamma$ LDR induced the damage effects on the spleen, thymus and testicle, and cimetidine alleviated the damage effects of the three organs in irradiated rats.

\section{Effect of cimetidine on the DNA content of bone marrow cells}

The results are shown in Fig. 1. The DNA content of bone marrow cells in the radiation model group was decreased significantly compared with that in the normal control group $(P<0.01)$, and the DNA content in the cimetidine groups was increased compared with that in the radiation model group $(P<0.01$ in the $20 \mathrm{mg} /(\mathrm{kg} \cdot \mathrm{d})$ cimetidine group and $P<0.05$ in the $80 \mathrm{mg} /(\mathrm{kg} \cdot \mathrm{d})$ cimetidine group). These results suggested that bone marrow cells are damaged by $n-\gamma$ LDR, and cimetidine has a protective effect on the DNA of bone marrow cells in irradiated rats.

\section{Effect of cimetidine on ConA-induced splenocyte proliferation}

Figure 2 shows that ConA-induced splenocyte proliferation in the radiation model group was decreased significantly compared with that in the normal control group $(P<0.01)$, while in the $20 \mathrm{mg} /(\mathrm{kg} \cdot \mathrm{d})$ or $80 \mathrm{mg} /(\mathrm{kg} \cdot \mathrm{d})$ cimetidine group was increased significantly compared with that in the radiation model group $(P<0.05)$. The results suggested that $n-\gamma$ LDR have an injured effect on the splenocytes of the irradiated rats, and cimetidine ameliorated the damage, thus improving the splenocyte proliferation in irradiated rats.

\section{Effect of cimetidine on SOD, GSH-Px and MDA in serum and hepatic tissue}

Table 4 shows that the SOD activity in serum and hepatic tissue of the radiation model group was decreased significantly compared with that of the normal control group $(P<0.01)$, and the SOD activity in the $20 \mathrm{mg} /$ $(\mathrm{kg} \cdot \mathrm{d})$ and $160 \mathrm{mg} /(\mathrm{kg} \cdot \mathrm{d})$ cimetidine group of serum and in the $20 \mathrm{mg} /(\mathrm{kg} \cdot \mathrm{d})$ cimetidine group of hepatic tissue were increased significantly compared with that in the radiation model group $(P<0.05$ or $P<0.01)$. Table 5 shows that the GSH-Px activity in the serum of the radiation model group was decreased significantly

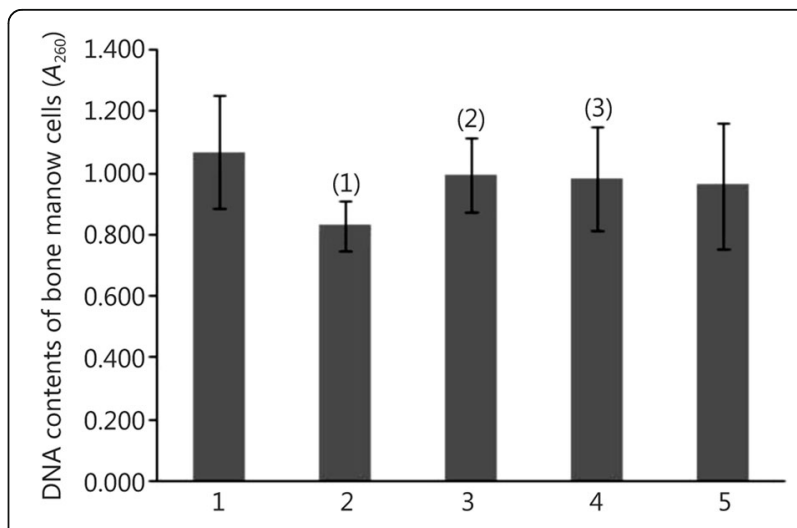

Fig. 1 Effect of cimetidine on the DNA content of bone marrow cells in irradiated rats. 1. Normal control group; 2. Radiation model group; 3. $20 \mathrm{mg} /(\mathrm{kg} \cdot \mathrm{d})$ cimetidine group; $4.80 \mathrm{mg} /(\mathrm{kg} \cdot \mathrm{d})$ cimetidine group; 5 . $160 \mathrm{mg} /(\mathrm{kg} \cdot \mathrm{d})$ cimetidine group. (1) $P<0.01$ compared with the normal control group; (2) $P<0.01$, (3) $P<0.05$ compared with the radiation model group 


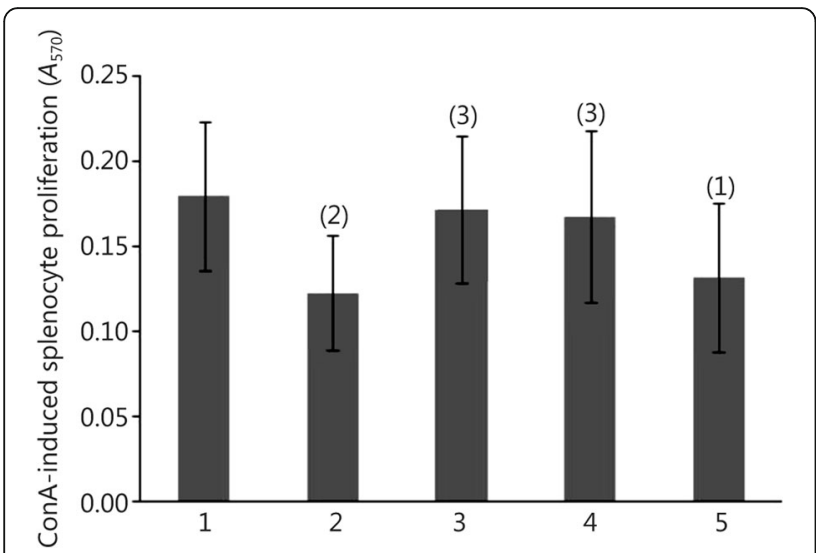

Fig. 2 Effect of cimetidine on ConA-induced splenocyte proliferation in rats. 1. Normal control group; 2. Radiation model group; $3.20 \mathrm{mg} /(\mathrm{kg} \cdot \mathrm{d})$ cimetidine group; $4.80 \mathrm{mg} /(\mathrm{kg} \cdot \mathrm{d})$ cimetidine group; $5.160 \mathrm{mg} /(\mathrm{kg} \cdot \mathrm{d})$ cimetidine group. (1) $P<0.05$, (2) $P<0.01$ compared with the normal control group; (3) $P<0.05$ compared with the radiation model group

compared with that of the normal control group $(P<$ $0.05)$, and the GSH-Px activity in serum of the $20 \mathrm{mg} /$ $(\mathrm{kg} \cdot \mathrm{d})$ and $80 \mathrm{mg} /(\mathrm{kg} \cdot \mathrm{d})$ cimetidine group was increased significantly compared with that of the radiation model group $(P<0.05)$. The GSH-Px activity in hepatic tissue showed no significant difference of all groups $(P>0.05)$. These results suggested that $\mathrm{n}-\gamma \mathrm{LDR}$ decreased the antioxidation activities of rats, and cimetidine had the effect of stimulating the activities of antioxidation in $n-\gamma$ LDR rats. Table 6 shows that the MDA in serum and hepatic tissue of the radiation model group was increased significantly compared with that of the normal control group $(P<0.05$ or $P<0.01)$. The content of MDA in the $20 \mathrm{mg} /(\mathrm{kg} \cdot \mathrm{d})$ and $160 \mathrm{mg} /$ $(\mathrm{kg} \cdot \mathrm{d})$ cimetidine group in serum and in all cimetidine groups in hepatic tissue was decreased remarkably compared with that in the radiation model group $(P<0.05$ or $P<0.01)$. These results suggested that cimetidine had the effect of stimulating serum and hepatic tissue MDA elimination in $\mathrm{n}-\gamma \mathrm{LDR}$ rats.

Table 4 Effect of cimetidine on SOD activity in serum and hepatic tissues of $n-y$ LDR rats $(x \pm s, n=10)$

\begin{tabular}{lll}
\hline Group & $\begin{array}{l}\text { SOD in } \\
\text { serum }(U / m l)\end{array}$ & $\begin{array}{l}\text { SOD in hepatic tissue } \\
(\mathrm{U} / \mathrm{mg} \text { protein })\end{array}$ \\
\hline Normal control group & $20.22 \pm 0.94$ & $174.01 \pm 20.84$ \\
Radiation model group & $15.04 \pm 1.60^{(2)}$ & $142.99 \pm 4.03^{(2)}$ \\
$20 \mathrm{mg} /(\mathrm{kg} \cdot \mathrm{d})$ cimetidine group & $19.75 \pm 5.39^{(4)}$ & $184.25 \pm 7.59^{(4)}$ \\
$80 \mathrm{mg} /(\mathrm{kg} \cdot \mathrm{d})$ cimetidine group & $16.26 \pm 3.60^{(1)}$ & $137.87 \pm 26.99^{(2)(5)}$ \\
$160 \mathrm{mg} /(\mathrm{kg} \cdot \mathrm{d})$ cimetidine group & $17.47 \pm 2.13^{(2)(3)}$ & $141.59 \pm 11.04^{(2)(5)}$ \\
\hline
\end{tabular}

${ }^{(1)} P<0.05,{ }^{(2)} P<0.01$ compared with the normal control group; ${ }^{(3)} P<0.05$, ${ }^{(4)} P<0.01$ compared with the radiation model group; ${ }^{(5)} P<0.05$ compared with the $20 \mathrm{mg} /(\mathrm{kg} \cdot \mathrm{d})$ cimetidine group
Table 5 Effect of cimetidine on GSH-Px activity in serum and hepatic tissues of $n-\gamma$ LDR rats $(x \pm s, n=10)$

\begin{tabular}{llc}
\hline Group & $\begin{array}{l}\text { GSH-Px in } \\
\text { serum }(U / \mathrm{ml})\end{array}$ & $\begin{array}{l}\text { GSH-Px in hepatic } \\
\text { tissue (U/mg protein) }\end{array}$ \\
\hline Normal control group & $1533.07 \pm 222.34$ & $230.67 \pm 37.99$ \\
Radiation model group & $1307.20 \pm 178.43^{(1)}$ & $215.73 \pm 21.05$ \\
$20 \mathrm{mg} /(\mathrm{kg} \cdot \mathrm{d})$ cimetidine group & $1455.85 \pm 103.16^{(2)}$ & $208.6 \pm 12.90$ \\
$80 \mathrm{mg} /(\mathrm{kg} \cdot \mathrm{d})$ cimetidine group & $1466.47 \pm 173.53^{(2)}$ & $222.94 \pm 29.92$ \\
$160 \mathrm{mg} /(\mathrm{kg} \cdot \mathrm{d})$ cimetidine & $1423.29 \pm 191.34$ & $210.05 \pm 32.30$ \\
group & &
\end{tabular}

${ }^{(1)} P<0.05$ compared with the normal control group; ${ }^{(2)} P<0.05$ compared with the radiation model group

\section{Effect of cimetidine on the fMNPCE in rat bone marrow erythrocytes}

The results are shown in Fig. 3 and Table 7. The fMNPCE in the radiation group was increased significantly compared with that in the normal control group $(P<0.01)$, and the fMNPCE values in the three cimetidine-treated groups were decreased significantly compared with that in the radiation model group $(P<$ $0.01)$. The DRF values of $M N$ in the $20 \mathrm{mg} /(\mathrm{kg} \cdot \mathrm{d})$, $80 \mathrm{mg} /(\mathrm{kg} \cdot \mathrm{d})$ and $160 \mathrm{mg} /(\mathrm{kg} \cdot \mathrm{d})$ cimetidine group were $1.41,1.77$ and 1.59 , respectively. These results suggested that cimetidine reduced the number of micronuclei in bone marrow polychromatic erythrocytes of irradiated rats, and protected against DNA damage induced by radiation.

\section{Discussion}

Cimetidine can protect cells against the clastogenic effects of $\gamma$-rays or low-dose fast neutrons $[6-9,11]$. However, there have been no reports on the effects of lowdose-neutron combined $\gamma$-rays. In our study, the rats were treated with whole-body $\mathrm{n}-\gamma \mathrm{LDR}$ and administered cimetidine at 20,80 and $160 \mathrm{mg} /(\mathrm{kg} \cdot \mathrm{d})$ by intragastric infusion. The results showed that the fMNPCE of all cimetidine-treated rats was reduced remarkably, with a DRF of 1.41, 1.77 and 1.59, respectively. This suggested that cimetidine can protect bone marrow polychromatic erythrocytes against the clastogenic effects of $n-\gamma$ LDR.

Table 6 Effect of cimetidine on MDA in serum and hepatic tissues of $n-\gamma$ LDR rats $(x \pm s, n=10)$

\begin{tabular}{lll}
\hline Group & $\begin{array}{l}\text { MDA in serum } \\
(\mathrm{nmol} / \mathrm{ml})\end{array}$ & $\begin{array}{l}\text { MDA in hepatic tissue } \\
(\mathrm{nmol} / \mathrm{mg} \text { protein })\end{array}$ \\
\hline Normal control group & $3.67 \pm 0.431$ & $4.18 \pm 0.60$ \\
Radiation model group & $4.02 \pm 0.37^{(2)}$ & $4.89 \pm 0.28^{(1)}$ \\
$20 \mathrm{mg} /(\mathrm{kg} \cdot \mathrm{d})$ cimetidine group & $3.70 \pm 0.36^{(3)}$ & $4.34 \pm 0.29^{(4)}$ \\
$80 \mathrm{mg} /(\mathrm{kg} \cdot \mathrm{d})$ cimetidine group & $3.83 \pm 0.40$ & $4.35 \pm 0.53^{(3)}$ \\
$160 \mathrm{mg} /(\mathrm{kg} \cdot \mathrm{d})$ cimetidine group & $3.50 \pm 0.38^{(4)}$ & $4.27 \pm 0.30^{(4)}$
\end{tabular}

${ }^{(1)} P<0.05$, ${ }^{(2)} P<0.01$ compared with the normal control group; ${ }^{(3)} P<0.05$,

${ }^{(4)} P<0.01$ compared with the radiation model group 

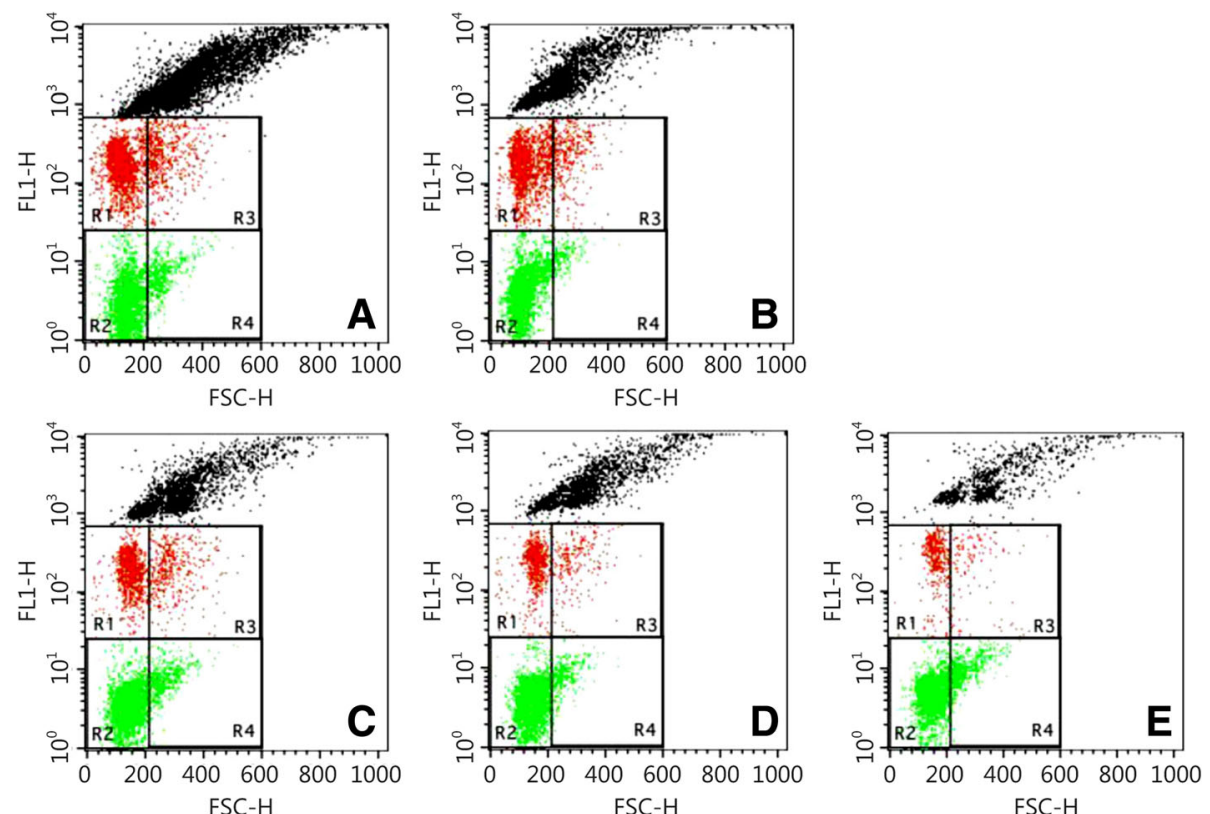

Fig. 3 FACS of rats on the frequencies of micronucleated polychromatic erythrocytes. a Normal control group; b Radiation model group; c $20 \mathrm{mg} /(\mathrm{kg} \cdot \mathrm{d})$ cimetidine group; $\mathbf{d} 80 \mathrm{mg} /(\mathrm{kg} \cdot \mathrm{d})$ cimetidine group; e $160 \mathrm{mg} /(\mathrm{kg} \cdot \mathrm{d})$ cimetidine group

Ionizing radiation (IR) injury has been attributed to reactive oxygen species (ROS)-mediated lipid peroxidation, which can be estimated by measuring the concentration of MDA. In the present study, cimetidine treatment rats showed significantly reduced MDA levels in the serum and liver, suggesting that cimetidine may diminish $n-\gamma$ LDR injury by decreasing ROS levels and reducing oxidative damage.

Biological systems protect themselves against the damaging effects of activated species by several means, including free radical scavengers and enzymes such as SOD and the GSH-Px system. It was reported that antioxidants could reduce IR injury. $\mathrm{H}_{2}$-receptor antagonists are scavengers of hydroxyl radicals with a very high rate constant $[8,18]$. They can stimulate SOD activity and decrease the MDA concentration in the blood of patients with peptic ulcer disease [19]. Mice treated with cimetidine could tolerate biomembrane damage provoked by sublethal

Table 7 Effect of cimetidine on the fMNPCE in bone marrow erythrocytes of $n-\gamma$ LDR rats $(x \pm s, n=10)$

\begin{tabular}{lll}
\hline Group & fMNPCE $(\%)$ & DRF \\
\hline Normal control group & $0.150 \pm 0.0216$ & - \\
Radiation model group & $0.410 \pm 0.0267^{(1)}$ & - \\
$20 \mathrm{mg} /(\mathrm{kg} \cdot \mathrm{d})$ cimetidine & $0.290 \pm 0.0213^{(1)(2)}$ & 1.41 \\
$80 \mathrm{mg} /(\mathrm{kg} \cdot \mathrm{d})$ cimetidine & $0.231 \pm 0.0325^{(1)(2)}$ & 1.77 \\
$160 \mathrm{mg} /(\mathrm{kg} \cdot \mathrm{d})$ cimetidine & $0.258 \pm 0.0268^{(1)(2)}$ & 1.59 \\
\hline
\end{tabular}

${ }^{(1)} P<0.01$ compared with the normal control group; ${ }^{(2)} p<0.01$ compared with the radiation model group; "-". No data $\gamma$-radiation [15]. The results in this study showed that SOD and GSH-Px activities in the serum were decreased significantly in $\mathrm{n}-\gamma$ LDR rats. The activity of SOD and GSH-Px was increased by treatment with cimetidine. Treatment with cimetidine possibly inhibited the accumulation of $n-\gamma$ LDR-induced free radicals, decreased the oxidative stress and protected the antioxidant enzymes of rats as revealed by the enhanced activities of SOD and GSH-Px in this study. The results supported the hypothesis that cimetidine might afford an efficient protection against IR or diseases that were characterized by in vivo free radical-mediated oxidative stress mechanisms [15].

Radiation-induced lymphohematopoietic syndrome is characterized by a depression in the peripheral blood levels of white and red blood cells and platelets, as well as the loss of weight and decrease in the size of lymphatic tissues such as the spleen and thymus gland. In this study, cimetidine was shown to have an effect of increasing the number of WBC and DNA content of bone marrow cells. These results suggested that cimetidine may play an important role in protecting the hematopoietic system against $n-\gamma$ LDR in vivo. This study also showed that the spleen indexes, thymus indexes and splenocyte proliferation of cimetidine-treated rats were increased significantly. It also suggested that cimetidine can improve the immune function of irradiated rats. Recent studies have shown that cimetidine could modulate immune responses. Cimetidine might act as a non-specific stimulant of cell-mediated immunity and as an immunomodulator [20], and enhances antigen-specific IgE and 
Th2 cytokine production [21]. Cimetidine augments Th1/Th2 dual polarized immune responses to recombinant HBV antigens [22]. It has also been revealed that a group of $\mathrm{T}$ cells with histamine receptors might have a suppressive effect. Therefore, an antagonist of histamine type II receptors might play a role in the immune system and inhibit the function of suppressor T cells, mainly by increasing the $\mathrm{CD} 4^{+}$cells of peripheral blood $\mathrm{T}$ lymphocytes $[13,23]$. The administration of cimetidine prior to irradiation leads to the inhibition of $\mathrm{T}$ suppressor cells and an increase in the proliferation of $\mathrm{CD}^{+}$lymphocytes, causing the production of glutathione reductase and catalase enzymes, which prevent DNA damage and eventually reduce the clastogenic effect of radiation $[13,24]$. Thus, cimetidine might, via the regulation $\mathrm{T}$ lymphocytes, protect rats against immune and oxidative damage by $n-\gamma$ LDR. These results suggested that cimetidine may be a useful candidate radioprotector for low-dose occupational radiation.

\section{Conclusion}

The effect of cimetidine on rats exposed to long-term $n-\gamma$ LDR was evaluated in this study. The results showed that cimetidine increased the peripheral blood WBC, spleen, thymus and testicle indexes, DNA content of marrow cells, lymphocyte proliferation, and activities of SOD and GSH-Px in $n-\gamma$ LDR rats significantly but reduced the frequency of micronuclei in polychromatic erythrocytes (1.41-1.77 fold) and effectively decreased the content of MDA in $n-\gamma$ LDR rats. The results suggested that cimetidine can alleviate damage induced by $\mathrm{n}-\gamma \mathrm{LDR} v i$ antioxi- $^{-}$ dation and immunomodulation. Cimetidine might be useful as a potent radioprotector for radiotherapy patients as well as occupational exposure workers.

\section{Abbreviations \\ AET: Aminoethylisothiouronium; ConA: Concanavalin A; DRF: Dose reduction factor; FBS: Fetal bovine serum; fMNPCE: Frequency of micronuclei in polychromatic erythrocytes; GSH-Px: Glutathione peroxidase; IR: Ionizing radiation; LET: Low linear energy transfer; MDA: Malondialdehyde; MEA: Mercapto-ethylamine; n-y LDR: Low-dose-rate neutron and $y$-ray combined irradiation; ROS: reactive oxygen species; SD: Sprague-Dawley; SOD: Superoxide dismutase; WBC: White blood cell}

\section{Acknowledgements}

None.

\section{Funding}

This study was supported by the Research Fund of National Science and Technology Major Project of China (No. 2014ZX09J14103-07B).

\section{Availability of data and materials}

The raw datasets from the study and/or those analyzed during the current study are available from the corresponding author on reasonable request.

\section{Authors' contributions}

DJ participated in the design of the study, carried out the immunoassays, performed the statistical analysis and drafted the manuscript. QW participated in the design of the study and SOD and MDA tests. XS participated in the design of the study and as an advisor. YH carried out testing the frequency of micronuclei in polychromatic erythrocytes and helped to draft the manuscript. TQ participated in administering the rats intragastrically and feeding the rats. QL carried out WBC testing. DH carried out the DNA content analysis of marrow cells. YL carried out GSH-Px testing in serum and liver tissues. WC participated in animal feeding and immunoassays. XR was responsible for rat irradiation. KL participated in organ indexes of irradiation rats. All of the authors read and approved the final manuscript.

\section{Competing interests}

The authors declare that they have no competing interests.

\section{Consent for publication}

Not applicable.

\section{Ethics approval}

The Institutional Animal Care and Use Committees of the Naval Medical Research Institute approved all procedures for animal care and treatment.

Received: 30 March 2016 Accepted: 18 February 2017

Published online: 27 February 2017

\section{References}

1. Komatsu K, Sawada S, Takeoka S, Kodama S, Okumura Y. Dose rate effects of neutrons and gamma-rays on the induction of mutation and oncogenic transformation in plateau-phase mouse m5S cells. Int J Radiat Biol. 1993;63(4):469-74.

2. Vral A, Verhaegen F, Thierens $H$, De Ridder L. Micronuclei induced by fast neutrons versus ${ }^{60} \mathrm{Co}$ gamma-rays in human peripheral blood lymphocytes. Int J Radiat Biol. 1994:65(3):321-8.

3. Patt HM, Mayer $\mathrm{SH}$, Strabe RL, Jackson EM. Radiation dose reduction by cysteine. J Cell Compar Physiol. 1953;42(3):327-41.

4. Durand RE. Radioprotection by WR2721 in vitro at low oxygen tension: implication for its mechanisms and actions. Br J Cancer. 1983;47(3):387-92.

5. Cairnie AB. Adverse effects of the radioprotector WR2721. Radiation Res. 1983;94(1):221-6.

6. Ghorbani M, Mozdarani $\mathrm{H}$. In vitro radioprotective effects of histamine $\mathrm{H} 2$ receptor antagonists against gamma-rays induced chromosomal aberrations in human lymphocytes. Iran J Radiat Res. 2003;1(2):99-104.

7. Mozdarani $\mathrm{H}$. Radioprotective properties of histamine $\mathrm{H} 2$ receptor antagonists: present and future prospects. J Radiat Res. 2003;44(2):145-9.

8. Kojima Y, Kondo T, Zhao QL, Shoji M, Futatsuya R. Protective effects of cimetidine on radiation-induced micronuclei and apoptosis in human peripheral blood lymphocytes. Free Radic Res. 2002;36(3):255-63.

9. Mozdarani H, Gharbali A. Radioprotective effects of cimetidine in mouse bone marrow cells exposed to gamma-rays as assayed by the micronucleus test. Int J Radiat Biol. 1993;64(2):189-94.

10. Mozdarani $H$, Vessal NJ. Cimetidine can modify the effects of whole body gamma irradiation on lymphohematopoietic systemes. Med J IR Iran. 1993;7(2):95-9.

11. Mozdarani H, Khoshbin-Khoshnazar A. In vivo protection by cimetidine against fast neutron-induced micronuclei in mouse bone marrow cells. Cancer Lett. 1998;124(1):65-71.

12. Mozdarani $H$, Salimi M, Froughizadeh M. Effect of cimetidine and famotidine on survival of lethally gamma irradiated mice. Iran J Radiat Res. 2008;5(4):187-94.

13. Sahasrabudhe DM, McCune CS, O'Donnell RW, Henshaw EC. Inhibition of suppressor T lymphocytes (Ts) by cimetidine. J Immunol. 1987;138(9):2760-3.

14. Lapenna D, De Gioia S, Mezzetti A, Grossi L, Festi D, Marzio L, et al. $\mathrm{H}_{2^{-}}$ receptor antagonists are scavengers of oxygen radicals. Eur J Clin Invest. 1994;24(7):476-81.

15. Kabodanian Ardestani S, Mahmood Janlow M, Kariminia A, Tavakoli Z. Effect of cimetidine and ranitidine on lipid profile and lipid peroxidation in $\gamma$ - irradiated mice. Acta Med Iran. 2004;42(3):198-204.

16. Shahidi M, Mozdarani H. Potent radioprotective effect of therapeutic doses of ranitidine and famotidine against gama-rays induced micronuclei in vivo. Iran J Radiat Res. 2003;1:29-35.

17. Jiang DW, Zhang J, He Y, Liu YM, Chen W, Liu Q, et al. Effect of Ganoderma capsule on immune regulation and peripheral blood cells in mice. Chin Hosp Pharm J. 2013;33(6):429-32 [Article in China].

18. Ching TL, Haenen GR, Bast A. Cimetidine and other $\mathrm{H}_{2}$ receptor antagonists as powerful hydroxyl radical scavengers. Chem Biol Interact. 1993;86(2):119-27. 
19. Kedziora-Kornatowska K, Tkaczewski W, Blaszcyk J, Buczynski A, Chojnacki J, Kedziora J. Effect of the $\mathrm{H}_{2}$-histamine receptor antagonist on oxygen metabolism in some morphotic blood elements in patients with ulcer disease. Hepatogastroenterology. 1998;45(19):276-80

20. Hosseinifard SM, Ahmadpour A, Mojazi Amiri B, Razeghi Mansour M, Ebrahimpour A. Immunomodulatory effect of cimetidine in common carp (Cyprinus carpio L.). Fish Physiol Biochem. 2013;39(6):1505-11.

21. Arae K, Oboki K, Ohno T, Hirata M, Nakae S, Taguchi H, et al. Cimetidine enhances antigen-specific lgE and Th2 cytokine production. Allergol Int. 2011;60(3):339-44.

22. Zhang W, Wang J, Su B, Li R, Ding Z, Kang Y, et al. Cimetidine augments Th1/Th2 dual polarized immune responses to recombinant HBV antigens. Vaccine. 2011;29(29-30):4862-8.

23. Asakage M, Tsuno NH, Kitayama J, Yamada J, Tsuchiya T, Yoneyama S, et al. The effect of cimetidine mainly increases $\mathrm{CD}^{+}$cells of peripheral blood T lymphocytes. Gan To Kagaku Ryoho. 2005;32(11):1576-7.

24. Mozdarani H. Can cimetidine be used as a radioprotector. J Iran Univ Med Sci. 1996;:106-17

Submit your next manuscript to BioMed Central and we will help you at every step:

- We accept pre-submission inquiries

- Our selector tool helps you to find the most relevant journal

- We provide round the clock customer support

- Convenient online submission

- Thorough peer review

- Inclusion in PubMed and all major indexing services

- Maximum visibility for your research

Submit your manuscript at www.biomedcentral.com/submit
Biomed Central 